\title{
Anne Hudson
}

\section{Poor preachers, poor men: Views of Poverty in Wyclif and his Followers}

Thomas Walsingham, in the course of his blood-curdling story of the Peasants' Revolt of 1381, gave an account of the sermon of John Ball before two thousand Kentish men assembled on Blackheath before their entry into London ${ }^{1}$. Ball's text, according to Walsingham, was not a biblical one but two lines of English verse:

Whan Adam dalf and Eve span,

Wo was thanne a gentilman?

Whether Walsingham was aware that the lines were not new, and had been used some years previously by no less a worthy than bishop Brinton, is unclear ${ }^{2}$. More interesting is his summary of the contents of Ball's ensuing sermon: all men had been created equal by God, who, had he wished there to be lords and servants, would have created these two orders in Eden; consequently all men should live as equals. To bring about this situation, men should strive first to kill the great lords of the kingdom, then the judges, justices and juries of the kingdom; then they should sieze the land of those they knew to be harmful to the community; there would then be peace and security in the future, equal liberty, nobility, dignity and power ${ }^{3}$. Ball's words so pleased the company, Walsingham adds, that they ac-

1 Thomas Walsingham, Historia Anglicana, ed. Henry T. Riley (Rolls Series, London 1863-4) ii.32-3, largely reproduced in Walsingham Chronicon Angliae, ed. Edward M. Thompson (Rolls Series, London 1874) 321-2; in addition to Walsingham, the most important, nearcontemporary accounts of the Revolt are those of the Anonimalle Chronicle, 1333-1381, ed. Vivien H. Galbraith (Manchester 1927), and of Henry Knighton, Chronicon ed. Joseph R. Lumby (Rolls Series, London 1889-95) ii.130-144. A convenient collection of these and other, mostly chronicle, accounts translated into modern English is The Peasants' Revolt of 1381, ed. R. Barrie Dobson (London 21983).

2 Mary A. Devlin (ed.), The sermons of Thomas Brinton, Bishop of Rochester (1373-1389) i, in: Camden Society third series 85 (1954) 154; Devlin dates this sermon to 12 March 1374. For other medieval English citations, which suggest that this is a traditional verse, see Bartlett J. Whiting and Helen W. Whiting, Proverbs, Sentences and Proverbial Phrases from English Writings mainly before 1500 (Cambridge Mass., London 1968) A38.

3 The Anonimalle Chronicle 137-8 contains a comparable account of Ball's advice to the rebels, though not presented as a sermon, as a result of which Ball 'fuist tenu entre les comunes come une prophete'. 
claimed Ball their future archbishop and chancellor of the kingdom; Ball alone was worthy of the first - saying that the present archbishop was a traitor to the commons and the kingdom, and that he should be beheaded wherever he might be found.

As Walsingham's audience would have appreciated, Ball's final exhortation had been followed to the letter in the events that ensued: Simon Sudbury, archbishop of Canterbury and chancellor of England, was beheaded by the rebels outside the Tower of London'. Equally, though it is not clear from other sources that the move actually had the approbation of the Revolt's leaders, the palace of the Savoy, the London house of John of Gaunt, duke of Lancaster, was sacked by the mob; that this may have been not wanton destruction nor greed for rich plunder, but in pursuit of Ball's ideal of human equality, is suggested by the report that the gold and rich jewels were thrown into the Thames and that the rebels themselves punished those of their fellows who kept any for themselves 5 . Walsingham, after this damning narration, reproduces Ball's letter to the commons of Essex, a letter of much less blatant instigation to rebellion, and then smugly concludes the history of Ball by narrating how Ball was hung, drawn and beheaded at St.Albans in July 1381 in the presence of the king, the body then being quartered and the four parts sent to four cities of the realm 6 .

The interest of this story for my present purpose lies in the fact that it appears as part of the narrative of Ball's trial, and occurs immediately after another claim by Walsingham: Ball 'docuit et perversa dogmata perfidi Johannis Wiclyf, et opiniones quas tenuit, et insanias falsas'. This claim in more ambivalent terms is made by Knighton when, in his account of Wyclif, he describes Ball as his precursor, the John the Baptist as it were; the later collection of materials, the Fasciculi Zizaniorum, describes Ball as Wyclif's sequax ${ }^{7}$. The views which, Walsingham alleged,

4 For recent commentary on the Revolt see The English Rising of 1381, ed. Rodney Hilton and Trevor H. Aston (Cambridge 1984), Essex and the Great Revolt of 1381, ed. W. H. Liddell, R. G. Wood (Essex Record Office 1982), and Nicholas Brooks, The Organization and Achievement of the Peasants of Kent and Essex in 1381, in: Studies in Medieval History presented to R. H. C. Davis, ed. Henry Mayr-Harting, Robert I. Moore (London and Ronceverte 1985) 247-70.

5 For the sack of the Savoy see primarily Walsingham Hist.Angl. i.457 repeated in Chron.Angl. 288-9; Knighton, 134-5; Anon.Chron. 141-2.

6 Hist.Angl. ii.33-34, Chron.Angl. 322; a fuller account of letters sent out by the rebels under various names including that of Ball is to be found in Knighton, 138-40, They have been discussed a number of times; see most recently Richard F. Green, John Ball's Letters: Literary History and Historical Literature in: Chaucer's England: Literature in Historical Context, ed. Barbara A. Hanawalt (Medieval Studies at Minnesota 4, Minneapolis 1992) pp.176-200; Steven Justice, Writing and Rebellion: England in 1381 (Berkeley, London 1994); and my paper: Piers Plowman and the Peasants' Revolt: a Problem Revisited, in: Yearbook of Langland Studies 8 (1994) 85-106.

7 Knighton, ii.151 'Hic [i.e. Wyclif] habuit praecursorem Johannem Ball, veluti Christus Johannem Baptistam, qui vias suas in talibus opinionibus praeparavit, et plurimos quoque doctrina sua, ut dicitur, perturbavit'; Fasciculi Zizaniorum, ed. Walter W. Shirley (Rolls Series, London 1858) 273. 
Ball had been disseminating for twenty years and more, certainly anticipated his Blackheath sermon: he had castigated both secular lords and ecclesiastical figures, but he had also long taught that no-one should give tithes unless he were richer than the parson to whom those tithes should be paid, and had urged that tithes and offerings should be withheld if it appeared that the payer led a better life than his curate ${ }^{8}$.

The connection of Wyclif with the Peasants' Revolt of 1381 is, of course, an issue that has been long and hotly debated, and is one without any easy resolution'. The coincidence of the Revolt with the ecclesiastical challenge to Wyclif's teaching on the eucharist in Oxford in the spring of the same year means that no chronicler of religious affiliations - and that covers almost all the consecutive histories of the Revolt - can avoid the charge of confusing the two affairs. Wyclif's Confessio, his response to the condemnation of his eucharistic views by the Oxford committee headed by William Berton, is dated 10 May 1381 ${ }^{10}$; the Revolt reached the outskirts of London on 13 June - the feast, as Margaret Aston has recently reminded us, of Corpus Christi day ${ }^{11}$. Wyclif's deplorable departure from theological orthodoxy in regard to the church's central sacrament retrospectively validated the 1377 condemnation of pope Gregory XI, a condemnation which had never been fully endorsed in England; that condemnation had selected a number of Wyclif's earlier opinions on dominion, the temporalities of the church and the ability of the secular powers to correct erring clerics ${ }^{12}$. To a dispassionate observer it might seem that those opinions, whilst hostile to the temporal aspirations of the clergy, were hardly incitement to the kind of civil rebellion that erupted in the Peasants' Revolt. But chroniclers of Walsingham's stripe could argue, with persuasive if not always logical force, that sedition against the secular powers was the in-

${ }^{8}$ Hist.Angl. ii.32, Chron.Angl. 320-1. Walsingham's twenty years was no exaggeration: Ball had certainly been in trouble with the authorities since 1355 at the latest; see Alison McHardy, The Church in London 1375-1392 (London 1977) xviii, 86, and Margaret Aston, Corpus Christi and Corpus Regni: Heresy and the Peasants' Revolt, in: Past and Present 143 (1994) $3-47$ at $21-3$.

9 See Herbert B. Workman, John Wyclif: a Study of the English Medieval Church (Oxford 1926) ii.237-40; K. Bruce McFarlane, John Wycliffe and the Beginnings of English Nonconformity (London 1952) 99-100; Joseph H. Dabmus, The Prosecution of John Wyclyf (New Haven 1952) 82-85; Margaret Aston, Lollardy and Sedition, 1381-1431, reprinted in her Lollards and Reformers (London 1984 - the paper first appeared in 1960) 3-7; Dobson, (above n.1), 373; my comments in: The Premature Reformation (Oxford 1988) 66-9.

10 Fasc.Ziz. 115-32; the deliberations of the Oxford committee are 109-13. The date is given on the copy of the text in Oxford MS Bodley 703, f.57ra. A longer version appears in four Hussite copies, and the continuation is printed by $I$. H. Stein, An unpublished fragment of Wyclif's Confessio, in: Speculum 8 (1933) 504-510. The whole of the text reappears in Wyclif's De apostasia, ed. Michael H. Dziewicki (Wyclif Society 1889) 213/2-16, 219/32-221/13, 222/40-229/37, 230/21-231/9 and the continuation, after a few lines, Wyclif Sermones iii, ed. Johann Loserth (Wyclif Society 1889) 278/7-286/30.

11 Aston, Corpus Christi.

12 The condemnation appears in Walsingham, Hist.Angl. i.345-356, the views pp.353-6. 
evitable extension of Wyclif's doctrine of dominion and of his attack on the material wealth and power of the church ${ }^{13}$.

It is not my purpose here to argue this case yet again. Whatever their polemical motivation, and however much that motivation slanted their judgment and consequently the accuracy of their reporting, many ecclesiastical contemporaries undoubtedly saw a connection between Wyclif's teaching and the Revolt. Wyclif's own comments on that Revolt in his De blasphemia have been taken by some critics as indicative of his hostility to the aims of the Revolt, and consequently of the improbability of his involvement with its course or its leaders ${ }^{14}$. But such critics, it seems, have concentrated on one or two remarks to the exclusion of their wider context. Wyclif did indeed deplore the beheading of the archbishop by rurales (190/20); it would have been better if the secular authorities had removed the cause of contention, the excessive temporalities of the church, in time to stop such an attrocity. The punishment exacted by the populace was indeed cruel and in their anger the rebels 'non plene fecerunt ad regulam' (190/17); but provocation had been offered by ecclesiastical incarceration of bona pauperum which should have been transferred to the relief of the community (190/25). As he had outlined earlier, 'particio indebita bonorum fortune est precipua causa perturbacionis ecclesie' (33/1), or 'inprovida distribucio bonorum fortune ex ceco titulo elemosine facit nimis magnam perturbacionem ecclesie' $(89 / 22)$ - the only change was the extension of that explanation from the church to the whole realm.

These statements, ambiguous at best, are, however, only the starting point in $D e$ blasphemia for Wyclif's much more extensive reflection upon the state of the country and upon the circumstances that could have produced the Revolt, an event which had evidently shocked even if it had not entirely surprised him. Like many of Wyclif's major works, the De blasphemia, the last book of his Summa theologie, fails to adhere closely to the plan and structure outlined at the start: a definition of blasphemy in the church, and an analysis of its twelve branches. Equally, like many of his writings, the text as it has been preserved, in seven complete manuscripts and two extracts, might appear to represent a partially revised or altered version of what Wyclif had originally written - the ninth branch of blasphemy, though its identity in the monastic orders is clear, is never fully described $^{15}$. But the apparent defect occurs precisely at the point at which references

13 And not only chroniclers: the Cistercian William of Rymington in his XLV Conclusiones written before autumn 1383 accused Wyclif of stirring up disturbances in London and elsewhere, and most notably on Corpus Christi day (i.e. 1381); see Oxford MS Bodley 158, f.202 where it forms part of the prologue - notably Wyclif in his reply (printed Opera Minora, ed. Johann Loserth (Wyclif Society 1913) 201-57 failed to deal with this charge.

14 Text ed. Michael H. Dziewicki (Wyclif Society 1893); for these critical deductions see the discussions listed above (n.9), McFarlane, 99-100, is most sceptical; but note Workman, ii.241-3; Dabmus, 85; Aston, 4.

15 The twelve branches are described as tortores, and the analysis begins in chapter 4 (54/ $15 \mathrm{ff}$.) with the pope; the ensuing chapters deal with the cardinals, the bishops and the archdeacons (caps. 5-7), with penance and implicitly confessors (caps. 8-11), with rural deans and cursorily rectors and inferior priests (cap. 12), as the second to eighth tortores. Chapter 13 
to the Peasants' Revolt intrude. Rather than later modification then, it seems more probable that the interruption reflects the precise chronology of Wyclif's writing. The opening twelve chapters allude many times to the debates of early 1381 in Oxford, and comment with new venom on the activities of the friars both in long established vices and in apparently new hostilities (such as their reluctance to share their books) ${ }^{16}$. But, though Wyclif's earlier ideas that Walsingham alleged resurfaced in the popular rising of 1381 are certainly repeated in these early chapters, the first overt mention of the Revolt is in chapter $13^{17}$. The remainder of the tract, though it adheres superficially to the analysis of the ninth to twelfth branches of blasphemy, is, it seems to me, dominated by that Revolt ${ }^{18}$.

The interest of those reflections for my present purpose lies in the way in which they combine many of Wyclif's long-held views about the correct relation of church and state with the precisely contemporary situation. The ideals, expressed in largely timeless terms in De civili dominio i, from which Gregory XI on the information of Adam Easton drew the condemned views in 1377, are now translated into concrete proposals for immediate and urgent political action ${ }^{19}$. The criticism of the actual ecclesiastical set-up had always been anchored all too blatantly in contemporary affairs, but the warnings that had accompanied that criticism could be shown in the second half of De blasphemia to have been fulfilled in the Revolt. The exhortations of De officio regis, that mirror for the young prince Richard II, a work of uncharacteristic terseness and coherence that may originally have been intended to follow directly on De civili dominio i, now require immediate political implementation ${ }^{20}$. The seven petitions to the king that are incorporated into $D e$

opens with the identification of the ninth as the possessioners (188/2), but within two pages Wyclif turns to the Revolt. Though the tenth to twelfth are identified in caps. 14-18, the discussion is constantly diverted into issues connected with the contemporary disturbances. The complete copies of the tract, all but one of them Hussite (including two not used by Dziewicki), do not appear to differ significantly in the text offered.

16 See for the first $62 / 8,89 / 27$; for the second for instance $75 / 20,86 / 12$ and the charge concerning books $21 / 5$.

17 For instance 52/28ff., 77/35ff., 81/15ff., 93/27ff., 109/19ff., 156/23ff.

18 Dziewicki in his introduction (vii-viii, xxxiii-xxxiv) implies that the Revolt is only seriously considered in chapter 13, though he mentions the later allusion to it in chapter 17 (267/ 10). Dziewicki (vii-viii) points to two allusions in the text that might refer to the Despenser crusade of $1383(156 / 27,191 / 29)$, but, as he says, they are uncharacteristically unspecific and probably refer to skirmishes incited by the papal rivals before that.

19 For the condemned views see above n.12; all but three of the nineteen are verbally identifiable, mostly in sequence, in: Reginald L. Poole and Johann Loserth (eds.), De civili dominio, 4 vols. (Wyclif Society 1885-1904) i.251-84, whilst the fourth, eighth and last are summaries of material to be found in the book. For Easton's involvement in supplying the information see William A. Pantin, The Defensorium of Adam Easton, in: English Historical Review 51 (1928) 675-80; I am grateful to Dr Margaret Harvey, who is currently preparing a fuller study of Easton's Defensorium, for confirmation of Pantin's suggestion.

20 The possibility that the De officio regis, Alfred W. Pollard, Charles Sayle (eds.) (Wyclif Society 1887), may have been intended to stand earlier in the Summa theologie arises from some cross-references in the text to chapters 'libri proximi' which seem only explicable as allusions 
blasphemia chapter $17(270 / 12-271 / 26)$ repeat old demands, demands that had been condemned by Gregory XI, but their significance is now altered ${ }^{21}$. The fourth is expressed tersely in Wyclif's accustomed terms: 'quod regni comunitas non oneretur talagiis insuetis, antequam totum patrimonium, quo clerus dotatur, deficiat. Patet, quia omnia ista sunt bona pauperum caritative exponenda ad eorum egenciam, vivente clero in perfeccione primarie paupertatis' (271/7). But this is the theorem that culminates from the preceding demonstration that the Revolt could have been stopped if the king, as he should, had taxed the clergy: 'si igitur clerus possessionatus, thesaurarius bonorum pauperum, reddidisset regi ipsorum pedagium, quomodo staret ista dissensio, inferens tantum malum?' (190/ 33). The sixth 'Quod rex nullum episcopum vel curatum mancipet suo ministerio seculari. Patet: quia aliter tam rex quam clerus foret proditor Jesu Cristi' (271/17) takes its force from the earlier assertion in regard to archbishop Sudbury (194/16) 'Quid, rogo, pertinet ad archiepiscopum occupare cancellariam regis, que est secularissimum regni officium?'

Wyclif acknowledged that the punishment exacted by the populus on the clergy in the Revolt was excessive quantitate, qualitate and modo (196/20-197/34) - in quantity, in that property not life should have been removed; in quality, because it was wrong to have killed the archbishop without allowing him to defend himself against his accusers; in manner, because malefactors, even the clergy, are entitled to punishment commensurate to their crime, because punishment should not be attempted against the secular rulers, and because judgment should not be given without due consultation. But the remedies Wyclif outlined to the dire situation of the country can hardly be regarded as comforting to either religious or secular leaders: the temporal possessions of the clergy 'potest quietare comunitates et dominos, ac de remedio perpetuo talis periculi providere' (201/20), and, even more provocatively, 'est enim error intollerabilis quod rex vel alius dominus regni super eius populum tiraniset' (197/39).

Dominating the whole of the last six chapters of De blasphemia is a profound anger, against the clergy, against the king, against the lords, for their collusion in allowing the country to come to a pass such that rebellion of this kind could occur. Despite the concern with the rejection of his own views of the eucharist, and his evident pain at the participation of the friars in that rejection, Wyclif constantly recurs to the issues of the Revolt: it is argued against him that many saints have defended clerical temporalities, and that by the same logic as he urges their deprivation could the deprivation of unjust secular owners be justified; but 'tam necessaria est illa sentencia, quod inpossibile est pacificare regna vel clerum complete

to De civili dominio i. A fuller analysis of these references, and of my suggestion that De officio regis may have been directed towards the young king, will be presented elsewhere. 21 For instance, the demand for confiscation of clerical wealth in the fourth (271/7) repeats the sixth and seventeenth condemned points (Hist.Angl. i.354-355) found in De civili dominio i.267/12 and 265/29 respectively; the final rejection of clerical powers of excommunication (271/20) picks up errors nine and ten (Hist.Angl. i.354) from De civili dominio i.274/ $15,276 / 7$. 
solvere sua debita, nisi illa sentencia fuerit per principes practisata' (283/30ff.). Whatever the doubts about the theory that Wyclif had urged since De civili dominio $\mathrm{i}$, the question was now, and had been for some time, a practical one - and to that there was only one answer.

How far is this wisdom after the event? can the concern for the commons, the apprehension of poverty as well as injustice as the underlying causes of unrest, be traced in Wyclif's earlier writings? does this search for a practical remedy outlast the immediate aftermath of the Revolt? did his followers continue the message of De blasphemia? In the rest of this paper I should like to begin to address these questions. Much has been written about Wyclif's theory of dominion, and about his views on fraternal begging, in both cases much about his debt to FitzRalph; though these matters are germane to any full consideration of the questions, I do not want here to go over this ground again ${ }^{22}$. Equally, though it is so central to my subject that I shall briefly return to it at the end, I shall not discuss all the thinking of Wyclif and his followers on the subject of disendowment ${ }^{23}$. What seems to deserve fuller scrutiny is Wyclif's views on the third estate: we know his views on poor preachers but what did he think about poor men?

In common with many earlier commentators, Wyclif did not condemn riches out of hand: the parable of Dives and Lazarus should not lead to the assumption that riches automatically damned a man, any more than poverty saved him - the poor man may not be able readily to indulge the sin of gluttony, but he was as subject to the temptations of the remaining sins as the rich man. Dives earned hell not because of his possession of wealth, but because he would not share it with the beggar at his gate ${ }^{24}$. Conversely, lack of goods is not in itself a virtue ${ }^{25}$. Expounding the parable of the unjust steward, Wyclif describes how the secular ruler needs to deal justly with riches, and deplores 'tanta inequalitas particionis'26. Wyclif's fullest and most nuanced discussion of poverty comes in De civili dominio iii chapters 7-10. The previous two chapters examine the position of Christ and, after his death, of the apostles in the early church - this should form the true model for later christian behaviour. The early church in holding in common did not hold civiliter (80/20). The perfection of life revealed by this model is not one

22 See, most notably, Aubrey Gwynn, The English Austin Friars in the Time of Wyclif (London 1940) especially 59-73; Michael Wilks, Predestination, Property and Power: Wyclif's Theory of Dominion and Grace, in: Studies in Church History 2 (1965) 220-36; Gordon Leff, Heresy in the Later Middle Ages, 2 vols. (Manchester 1967) ii.545-549; Katherine Walsh, A Fourteenth-Century Scholar and Primate: Richard FitzRalph in Oxford, Avignon and Armagh (Oxford 1981), especially 349-468; James D. Dawson, Richard FitzRalph and the Fourteenth-Century Poverty Controversy, in: Journal of Ecclesiastical History 34 (1983) $315-44$.

${ }^{23}$ See for this Margaret Aston "Caim's Castles: Poverty, Politics and Disendowment, reprinted in: Faith and Fire: Popular and Unpopular Religion 1350-1600 (London and Rio Grande 1993) 95-131.

24 Sermones 4 vols., ed. Johann Loserth (Wyclif Society 1887-90) i.224/1ff.

25 De civ.dom. iii.145/28 'remanet paupertas evangelica in temporalia affluencia'.

26 Sermones i.273/37. 
of simple negation of personal possession, but of shared communication of all good things, spiritual and material27. The singular pronouns meum, tuum and suum are repugnant since they imply proprietatem civilem (143/19); 'paupertas ... stat in perfecta abdicacione proprietatis et per consequens in abdicacione civilis dominii' $(85 / 13)^{28}$. This leads to the central concept of paupertas evangelica defined shortly afterwards: 'evangelica paupertas non habet nudam carenciam temporalium pro fundamento, quia illam carenciam stat viciosissimum habere temporalia quantumlibet sicientem sed fundatur in fervore caritatis quo quis gratis prescindit ab ipso possibilitatem occasionis usibilium unde Dei dileccio tardaretur' (89/13); this 'evangelica paupertas est scola Christi' (172/16). As emerges, the pauper evangelicus is to renounce possession civiliter: 'paupertas evangelica infert maius dominium quam aliquid ad quod quis secundum civilitatem potest attingere' $(113 / 24)^{29}$. Since Christ refused civil possession and declined to judge civiliter, the most fitting poverty lies in caritativa abdicacione civilitatis propter Christum et eciam in voluntaria communicacione temporalium' (130/17). But this abdication depends crucially on disposition (76/8): such poverty implies true humility (120/19); to this Wyclif repeatedly returns, as 'notandum tamen quod paupertas evangelica non est nuda privacio que est temporalium carencia, sed habitus animi, quo humilis abdicat a se temporalium civilitatem ut expedicius excolat Deum suum' (151/2). At this stage, as he acknowledges, Wyclif's views are comparable to the founding ideals of the monastic and fraternal orders; in later chapters, where Wyclif is answering Woodford's objections, the departure of the contemporary religious from those ideals is more fully stressed 30 .

But, as the English saying goes, fine words butter no parsnips - where does this leave those who, from adversity of birth or circumstance, cannot choose but go hungry, without clothing or lodging? Is not Wyclif's thinking limited to his preoccupation with the questions associated with clerical property? Whilst it may not be unfair to see his discussion as coloured by the claims and counterclaims of the clergy, and as framed in terms traditional in that long polemic, it would be wrong to argue that Wyclif gave no thought to the practical issues of civil society in his discussion here. The endowment of the church was intended by the laity not for the enrichment of the clergy but 'ad ministerium pauperum bona mundi' (217/17), and this is backed by gospels and epistles, and also by the canonists ${ }^{31}$. There may

27 De civ.dom. iii.78/26; for Wyclif's views on community of property see Anthony Kenny, Wyclif (Oxford 1985) 46-7, 108, and note De statu innocencie, Johann Loserth, Frederic D. Mattbew (eds.) (Wyclif Society 1922) 508/13 all things may be 'propria quoad habicionem relativam' but 'communia quoad usum'.

28 Cf. 147/19 the Lord's prayer does not ask for 'panem meum' but for 'panem vite communem' implied by the collective 'nostrum'.

29 Cf. De civ.dom. i.60/21, iii.73/15 where it is stated that civil possession is always tainted with sin.

30 De civ.dom. iii.108/9; later 405/19, 419/31ff., 478/3. Woodford's De dominio civili clericorum was edited by Eric Doyle, in: Archivum Franciscanum Historicum 66 (1973) 49-109, and is answered in De civ. dom. iii.351-405 (caps. 18-19).

31 The whole of chapter 14 is an anthology of canon law support for clerical poverty, culmi- 
be two kinds of possession, civiliter and ex nudo titulo gracie (143/29); the second should be that to which the christian should aspire, but the need for the first in this world is freely acknowledged. Evangelical poverty is of itself a virtue, whilst civil dominion is by definition an imperfect religion which can only be justified if it leads to evangelical poverty (161/26); 'civilis possessio ... implicat veniale peccatum' (161/43). This raises, as Wyclif acknowledged, a problem for the secular ruler. God, he argues, does not order civil dominion as such in scripture, but he ordains many acts of civil dominion as meritorious; civil dominion is itself only venial sin - the deadly sin of pride and of defect of charity are often inculcated by it (167/8). The temporalities of the church would be better dispensed if they were in the hands of laymen (334/33). In De officio regis Wyclif observes that nothing so readily destroys a kingdom 'quo ad vitam politicam, quam immoderate aufferre ab inferioribus bona fortune' (96/25); in practice subjects are obedient because the king dispenses goods wisely and rules prudently - departure from this, and particularly collusion in the appropriation of goods into the dead hand of the church, encourages revolt (97/34).

Wyclif's importance as a writer on political theory in the later medieval period has long been acknowledged; the implication of analysis of that theory has, however, often been that his ideas remain remote from the realm of actuality - his views on dominion, for example, to many historians of medieval thought were speculations without possible impact on the world of England in the reign of $\mathrm{Ri}$ chard II, or anywhere else ${ }^{32}$. Only the schemes for disendowment, adumbrated by Wyclif and more fully developed by his followers, we are assured by such critics, had any practical application. But some precise practical implications are drawn by Wyclif in De civili dominio iii: if a natural heir to property that has been given to the church finds himself in poverty, it is not right that the church should remain in possession (304/17); the layman who believes a cleric to have temporalities unjustly may bring the case to a civil court (309/18), and the king should organize scrutiny of clerical possessions, which scrutiny would certainly lead to confiscation $(314 / 2)^{33}$. Equally in De officio regis theory extends to specificities: the archbishop on admission swears allegiance to the king on behalf of the clergy (69/ 24), and hence admits the temporal subordination of the institutional church to the secular authority ${ }^{34}$; the king should not admit to England any priest unless he is prepared to swear such an oath of allegiance (108/2, cf. 164/1, 206/1); it is lawful for the king to pull down a church to build a defensive tower, or to melt chalices to pay his soldiers (185/9). Is it surprising that Wyclif's contemporaries saw his

nating (257/9-263/13) in seven conclusions concerning the implications and means of remedying this situation.

32 See, for instance, Leff, (above n.22), ii.549, and Jobn Stacey, Wyclif and Reform (London 1964) 63-4.

33 De civ.dom. ii.47/8ff., 51/17 gives historical examples of confiscation of clerical property in England in the past.

34 Cf. De civ.dom. ii.39/31 and the material from London MS BL Additional 24202 quoted below. 
teaching in a much more alarming light than the modern critics: Gregory XI's bull against Wyclif in 1377 selected precisely those views on dominion from De civili dominio i for condemnation, and the letter that accompanied that bull to England stressed the disruptive effects that such views could have on ecclesiastical and civil society. Later opponents saw those warnings only too accurately fulfilled in the Peasants' Revolt, to which they connected Wyclif as a prime instigator. As I have tried to show, whatever the causal relation between the Oxford academic and civil uprising, Wyclif's comments on that Revolt give the lie to any modern dismissal of his interest in contemporary actuality - and those comments on that actuality were far from reassuring to either church or secular ruler.

In the light of those comments it is worth looking at the way in which Wyclif's followers continued his political concern. At some point in 1382, probably early, Nicholas Hereford had openly proclaimed that Simon Sudbury had been juste slain, because he had desired to correct his master, John Wyclif, whose views he (Hereford) approved - and Hereford 'semper commovendo populum ad insurrectionem'; Philip Repingdon at the Corpus Christi day sermon 'excitavit ... populum ad insurrectionem, et ad spoliandas ecclesias' 35 . There is more information about Hereford's sermon on Ascension day 1382 in Oxford which survives in a copy of a notarial account commissioned immediately by Peter Stokes, the Cistercian messenger (or more accurately spy) of archbishop Courtenay; as the wording makes clear, for the most part only a précis of Hereford's words, which had been delivered in English not in academic Latin before his congregation of the Chancellor of the university and a multitude of clerics and of lay people, is provided given the purpose of Stokes, it is safe to assume that only the more provocative parts of the sermon were recorded ${ }^{36}$. The sermon, it should be remembered, was given on 15 May 1382, just eleven months after the Revolt had reached its climax in the murder of Sudbury, the destruction of the Savoy and the meeting of Richard with Wat Tyler. That this fact was in the mind of Stokes and of his notary John Fykyes is implicit in the declaredly verbatim account of Hereford's peroration, in which he lamented that the king had no officers to effect the disendowment of the clergy that he had been urging, and exhorted 'vos, o fideles Cristiani, manum apponere vt vos saltim hoc negocium ad finem debitum perducatis' (135). The corruption of all ranks of the church by their attachment to temporalities had been outlined in the preceding analysis; Hereford's description followed exactly in the steps of his master, and echoed older complaints by FitzRalph and others. Stokes could doubtless have amplified these words from his experience of the polemic,

35 Fasc.Ziz. 296, 299.

36 See the edition by Simon Forde, "Nicholas Hereford's Ascension Day Sermon 1382", in: Mediaeval Studies 51 (1989) 205-41. The manuscript, described 230-4, is now Oxford MS Bodley 240, where the sermon appears amongst a final miscellaneous collection of texts on pp.848b-50, but derives from Bury St.Edmunds; Forde, 234-6, makes a persuasive case for thinking that the text is 'a close copy of an original instrument'. 
and doubtless expected his ecclesiastical masters to be capable of the same ${ }^{37}$. But one or two comments are recorded that are more germane to this paper. At the start of his sermon Hereford outraged Stokes by praying for the king, the queen, the queen mother, the lord duke (unspecified but obviously the Duke of Lancaster, John of Gaunt, long time protector of Wyclif and, as they hoped, of his disciples), for all the lay rulers of the kingdom, for all those 'qui sunt spirituales postpositi Dei' (32), for the Chancellor and members of the university, for the mayor and community of Oxford, but not for the pope ${ }^{38}$. Hereford then apparently started 'Sicut Cristus diligit plus totam comunitatem quam aliquam eius personam, sic deberet quilibet homo plus diligere et zelare totam comunitatem et eius profectum quam particulare comodum alicuius persone singularis eiusdem' (35); he claimed that he had set himself to work entirely 'propter zelum comunitatis', in which cause he was prepared to labour and if necessary to suffer (40). To this concern with the community he returns after a condemnation of the self-interest of all ranks in the church, especially of the friars; turning to his immediate congregation he reproaches the greed of the bachelors, and the even more avaricious claims of the masters 'Et cum omnes sint eiusdem professionis et vnius comunitatis, ex quo inferiores contenti sunt modica parte bonorum comunium, quare non essent contenti superiores tam modico sicut illi?' $(106)^{39}$. Since all religious orders have more than they need for maintenance of life, 'si rex et regnum vellet eis auferre possessiones et thesauros eorum superfluous ut deberet, tunc non oporteret regem spoliare pauperem comunitatem regni per talagia sicut solet' (130). The similarity of wording between Hereford's words, as reported by Stokes, and Wyclif's comments in the De blasphemia is striking. Behind the notarial account, and colouring all its declaredly neutral reporting of the sermon that Ascension day, lie the events of the previous year, events that the poet John Gower described in the book that he added in first place to his completed Vox Clamantis as the action of 'tanta monstrorum more ferarum ... sicut arena maris ${ }^{40}$. And that Stokes was not being hysterical in his reporting seems plain from Hereford's peroration, a peroration which, if it bears any resemblance to what Hereford said, urged a repeat performance of that Revolt ad finem debitum ${ }^{41}$.

${ }^{37}$ See references Penn R. Szittya, The Antifraternal Tradition in Medieval Literature (Princeton 1986).

38 The outrage felt comes clearly through the words: after the long sequence of prayers, with its thrice reiterated 'inquit', 'et in tota recomendacione non fecit mencionem de summo pontifice specialem' (33-4).

39 Wyclif considered the avarice of academics, both corporately and individually, in De blasphemia 244/35ff.; compare the English texts cited below.

${ }^{40}$ George C. Macaulay (ed.), The Complete Works of John Gower, 4 vols. (Oxford 18991902) iv.679-80, "the great multitude of monsters like wild beasts ... a multitude like the sands of the sea".

41 135-8: 'Ideo oportet vos, o fideles Cristiani, manum apponere vt vos saltim hoc negocium ad finem debitum perducatis. Et tunc firmiter spero quod bene procedet, quia scio certissime quod ipse Deus omnipotens uult quod fiat.' 
Hereford's sermon can be dated, and precisely dated only a year after the Revolt. With most of the Lollard texts more uncertainty about dating exists, and more likelihood that a longer passage of time had elapsed since that event. But echoes of the concerns revealed in Wyclif's De blasphemia and in Hereford's sermon can be repeatedly found. Modern critics fasten the more avidly on the constant criticism of the clergy. But, alongside this preoccupation, the contrasting plight of the poor is not in the texts forgotten: the clergy 'laten pore men haue nakid sidis, and dede wallis haue grete plente of wast gold'; the exactions from the commons may not in financial terms amount to large sums, but 'it is in many caasis as myche synne to rob a wedewe or a pore fadirles child of a peny or an halpeny as it were to robbe a riche man of an hundrid markis-worth godis'; bishops in taking secular power cause dissension between men 'as risyngis of the puple and comunes a3en hem and ther lordis as doolfully we sawen late'42. Wyclif's view of evangelica paupertas is recalled when an English writer claims that worldly prelates rob the church 'of the tresour of wilful povert and mekenesse'43. Much detail is given of the ways in which the activities of churchmen work to the detriment of the poor commons. 'The sotil amortasynge of seculer lordischipis that is don bi menene hondis in fraude of the kyngis statute' should be remedied, to the advantage of the kingdom 'in sparynge of the pore comons of taxes'; 'Now the thrid dele $o$ the land es in her [sc.the clergy's] handes and [thei] ben waxen worldliche lordes that the comone popil es greteli anentisid therbi so ferforth that, when the kinge had nede to be holpen of his popel of taxes and other tallyages, thai ben no3t of mi3t to help the kinge'; the clergy, in following the decretal prohibition on payment of civil taxes without papal permission, give an example to the people to rebel against the king and lords ${ }^{44}$.

The results of the continuing accretion of property to the church are spelt out in immediately apprehensible terms: a gentleman asked a bishop how secular lords and knights should live, if the clergy had all the property, to which the bishop answered that 'thai schuld be clerkis soudyoures, and lyue by her wagis' 45 . Clerical claims of the inalienability of property given to the church produce both deplorable and also ridiculous consequences: deplorable in that the process diminishes the king's regalie 'and than were he no kinge bot as kinge in a somer game, or elles as a kinge paintid on a wall', ridiculous in that, if followed logically, a clerk would be unable to purchase food or other necessaries of life since he could not alienate the money needed ${ }^{46}$. The evils of the conveyance of wealth out of the

42 Frederic $D$. Mattbew (ed.), The English Works of Wyclif hitherto unprinted, in: Early English Text Society 74 (21902) 91/32, 417/31 and cf.127/29; the third from an unprinted tract in London BL Additional 24202, f.41. In all quotations of Middle English I have replaced thorn by th.

${ }^{43}$ Thomas Arnold (ed.), Select English Works of John Wyclif, 3 vols. (Oxford 1869-71) iii. $275 / 13$.

44 Mattherw, 278/34; unprinted dialogue in Durham University Library MS V.iii.6 f.10v; Arnold, iii.298/10.

45 Matthew, 368/28.

46 Durham dialogue f.17v; cf. Arnold, iii.516/2. 
country to the papacy by various means is frequently deplored: 'it is opin at the i3e to kunnynge men that, thou 3 oo greet hil of gold were in Ingelond, and no man outake siche Rome-renneris toke of it, $3 \mathrm{ea}$, a ferthing, al the gold shulde be borun out of the rewme bi hem to straungeris withynne a certeyn tyme'47.

The concept of the king's regalie is, for the writers of these texts, one of considerable potency but also a very practical matter. The Tractatus de regibus urges the need for the king to maintain his regalie, for which he needs money and men; those who claim exemption from taxation or from the processes of civil justice, as the clergy do, break the king's regalie, ensuring that 'kyngus bene not fulle lordes of her kyngedome' ${ }^{38}$. The kings and the lords are intimidated by clerks who curse them if they attempt to reclaim goods 'as 3 if seculer lordis and the comyns weren no part of holy chirche'49.

Many of these ideas are, of course, traditional; some of them are uncanny echoes of the doctrines of the accursed Marsilius of Padua - whom Gregory XI in his bull asserted had been the teacher of Wyclif ${ }^{50}$. Others are more distinctively derived from Wyclif, in their terminology as in their ideas. Even if Wyclif himself is rarely mentioned by name, important events in his history are sometimes specified: the friars at the Earthquake Council condemned the view that tithes are alms and can be withheld and given to poor men; the friars at the Blackfriars Council condemned as heretical the idea of disendowment; the clergy at the Earthquake Council cursed those who attempted to take anything from the church ${ }^{51}$. In each of these three allusions, deriving from three different texts, the Council is associated not with condemnation of Wyclif's eucharistic views, but with his views about the temporalities of the church. More specifically an unprinted text alleges that the clergy reply to charges against their ill-gotten wealth with the claim 'in this wise profesiede of vs Lincoln, Bradewardyn, Armacan, Kilmyngton, Wiclyue, and manye othere - and, in tocne that ther profecie is but desiryng of veniaunce of ther owne enuye, thei hemself persheden and we ben euere the lengere the strengere'52. The patrimony, of Grosseteste, Bradwardine, FitzRalph and his ally Kilmyngton, would not, I think, have displeased Wyclif, and suggests that one later Lollard writer at least was aware of a heritage that derived from before 1381 .

${ }^{47}$ Josiab Forshall (ed.), Thirty-Seven Conclusions of the Lollards, printed under the title of Remonstrance against Romish Corruptions (London 1851) 88, here quoted from BL Cotton Titus D.i f.49; cf. Mattberw, 22/32, 23/15, 223/30.

48 Tractatus de regibus, ed. Jean-Philippe Genet, Four English Political Tracts of the Later Middle Ages, in: Camden Society 4th series 18 (1977) 10/5; cf. Arnold, iii.391/8, 495/20; Matthere, 292/3.

49 Arnold, iii.275/33.

50 This is not the place to investigate the vexed question of that asserted influence. Wyclif never mentions Marsilius, or quotes him by name, and it seems doubtful whether the Defensor pacis was available in England before 1400; but any reader of that text followed by many of Wyclif's mature writings must be struck by the similarities.

51 Three different texts in Arnold, iii.175/22, 233/3, 313/20.

52 BL Additional 24202, f.53v. 